Research Article

\title{
Structural Construction of Binders Based on Orthophosphoric Acid and Refractory Materials
}

\author{
R. Liutyi, ${ }^{1}$ D. Liuta, ${ }^{1}$ and I. Petryk $\mathbb{D}^{2}$ \\ ${ }^{1}$ National Technical University of Ukraine "Igor Sikorsky Kyiv Polytechnic Institute", Peremohy Avenue 37, 03056, Kyiv, Ukraine \\ ${ }^{2}$ Ivano-Frankivsk National Technical University of Oil and Gas, Karpatska Str. 15, 76019, Ivano-Frankivsk, Ukraine \\ Correspondence should be addressed to I. Petryk; iyap@ukr.net
}

Received 4 December 2020; Accepted 15 February 2021; Published 25 February 2021

Academic Editor: Robert Černý

Copyright $\odot 2021$ R. Liutyi et al. This is an open access article distributed under the Creative Commons Attribution License, which permits unrestricted use, distribution, and reproduction in any medium, provided the original work is properly cited.

The formation of phosphate binders in systems based on orthophosphoric acid and the most common refractory fillers in foundry technology (quartz dust, zircon $\mathrm{ZrSiO}_{4}$, and kyanite-sillimanite $\mathrm{Al}_{2} \mathrm{SiO}_{5}$ ) has not been previously studied. The phase composition of these inorganic binders was studied, and the formation of silicon $\mathrm{SiP}_{2} \mathrm{O}_{7}$ and zirconium $\mathrm{ZrP}_{2} \mathrm{O}_{7}$ pyrophosphates was confirmed. The study by differential thermogravimetric analysis in the temperature range of $20-1000^{\circ} \mathrm{C}$ established the fact that the formed binders are thermally stable and do not emit harmful gaseous substances. The obtained results of the studied binders make it possible to develop new environment-friendly core mixtures of thermal hardening.

\section{Introduction}

The tasks of metallurgy and foundry production are the preparation of alloys and the manufacturing of products from them with a wide range of special properties that are used for both heavy industry $[1,2]$ and precision casting $[3,4]$. This requires the use of materials with high thermal and chemical resistance. Single-layer and double-layer microarc oxide coatings are used as protective heat-resistant coatings on cores and molds [5-8]. During the research of casting processes, it is possible to apply modeling of thermal processes in layered structures, for example, temperature distribution in the mold and casting $[9,10]$. For the manufacture of molds and cores, the volume of which is millions of tons per year, we usually use iron phosphate and magnesium phosphate mixtures $[4,11-14]$, which often contain scarce and substandard components.

Also, casting seeks to obtain a high-quality product with low cost and, very important, to meet stringent environmental standards. Conventional foundry binders are responsible for up to $70 \%$ of a foundry's volatile organic compound emissions [15]. The source of unsatisfactory environmental situation is also the spread of sand-resin mixtures [16-18]. New binder technologies are essential for both foundries and the environment.

A variety of binder systems have been developed predicated on a foundry's problems [14, 19-23]. Binders have been solving many problems by addressing the casting quality, productivity, and environmental attributes foundry men receive from their binders. The effects of binder parameters on the properties of ceramic products and their anisotropic shrinkage were investigated [24].

The use of phosphorus salts as binders for foundry metal production is poorly researched. The ability to bind and stick by phosphates is associated with the crystalline structure, which is due to the position of phosphorus in the periodic table of elements [25]. Phosphate materials, including binders, have been widely used in many fields of technology [10, 26-28].

The research of phosphates is of interest both from the scientific and technological point of view. $\mathrm{H}_{3} \mathrm{PO}_{4}$ and metal oxide, which acts as a hardener, are needed to obtain phosphates $[12,13,29,30]$. The use of other compounds instead of oxides (silicates, metal salts, etc.) has not yet been considered. In this case, it is noteworthy that the main refractory fillers used in the core mixtures to manufacture 
complex sand molds for metal casting are oxides of transition and acid elements $\left(\mathrm{SiO}_{2}, \mathrm{Al}_{2} \mathrm{O}_{3}\right.$, and $\left.\mathrm{ZrO}_{2}\right)$ [30] or silicates $\left(\mathrm{mAl}_{2} \mathrm{O}_{3} \cdot \mathrm{nSiO}_{2}, \mathrm{ZrO}_{2} \cdot \mathrm{SiO}_{2}\right.$, etc.) $[12,13]$. Both groups of compounds under normal conditions do not react with $\mathrm{H}_{3} \mathrm{PO}_{4}$, but such an interaction is possible when heated. It is known that the properties of materials, including nonmetallics or composites, are structurally dependent, so studies of phase and mineralogical composition play an important role $[31,32]$.

\section{Formulation of Research Problems}

Previous studies of new core mixtures, the strengthening of which occurs during heated due to the interaction of $\mathrm{H}_{3} \mathrm{PO}_{4}$ and refractory fillers, gave positive results. In particular, a mixture of $3-4 \%$ concentrated (85\%) acid and 5-10\% quartz dust, the filler of which is quartz sand, after hardening at $300^{\circ} \mathrm{C}$, has a compressive strength more than $2.5 \mathrm{MPa}$ with a scattering less than $0.30 \%$ [33]. A mixture of 3-4\% $\mathrm{H}_{3} \mathrm{PO}_{4}$ and $7-8 \%$ zirconium dust, the filler of which is zircon concentrate, after hardening at $350^{\circ} \mathrm{C}$, provides a similar level of properties. Mixtures of $\mathrm{H}_{3} \mathrm{PO}_{4}$ and additives of dusty aluminosilicates (pyrophyllite $\mathrm{Al}_{2}(\mathrm{OH})_{2}\left[\mathrm{Si}_{4} \mathrm{O}_{10}\right]$ or kyanite-sillimanite $\mathrm{Al}_{2} \mathrm{O}_{3} \cdot \mathrm{SiO}_{2}$ ) after hardening at $300^{\circ} \mathrm{C}$ provide a compressive strength of $1,4, \ldots, 3,2 \mathrm{MPa}$.

These properties make it possible to use these mixtures for the manufacture of foundry cores, which are strengthened by heating. However, there is currently no data on the mineralogical structure of the binder films and their phase composition, so it is not possible to predict the behavior of mixtures when heated in contact with the casting.

The aim of the study is to determine the phase and mineralogical composition of binders formed during the interaction of orthophosphoric acid with refractory fillers of different classes and to determine the processes that occur with these binders when heated to $1000^{\circ} \mathrm{C}$.

\subsection{Research Objectives}

(1) X-ray phase analysis of binders formed during the interaction of orthophosphoric acid with quartz, zircon, and aluminosilicates

(2) Investigation of the processes that take place in the newly formed binders during heating, polymorphic and other transformations, and general thermal stability

(3) Development of recommendations for the use of the investigated binders in the composition of foundry core mixtures, which are strengthened by heating

\section{Experimental Data}

A multifunctional diffractometer Rigaku Ultima IV was used to determine the phase composition of binders, which performed qualitative and quantitative analysis. The processes that occur during heating were determined using curves of differential thermogravimetric analyses taken from the STA 449 C Jupiter.
As we have previously established, the mixture based on quartz sand with $1-4 \%$ of orthophosphoric acid is strengthened when heated to $300-320^{\circ} \mathrm{C}$. The strength depends on the particle size characteristics of the sand. $2.5-10.0 \%$ of the quartz dust in the mixture stabilizes the strength and reduces the flakeability of the mixtures [34, 35]. Based on the analysis of the information presented above, it can be stated unequivocally that the strengthening of the mixtures is due to the formation of binders in them when heated. The binders are the product of the interaction of $\mathrm{H}_{3} \mathrm{PO}_{4}$ and silicon particles since there are no other impurities in the mixture. To ensure the purity of the experiment and eliminate the influence of the impurities, which inevitably are in the filler, the sample of new binders was synthesized from $85 \%-\mathrm{H}_{3} \mathrm{PO}_{4}$ and silicon dust. These components are mixed and withstood for 1 hour in a laboratory oven at $300^{\circ} \mathrm{C}$. The sample has become fully solid. After cooling, it was ground to the dust.

$\mathrm{X}$-ray analysis of the sample showed the presence of it completely new to the molding and core mixtures of the compounds (Figure 1). It is silicon pyrophosphate $\mathrm{SiP}_{2} \mathrm{O}_{7}$, whose lines are marked on the diffraction pattern. In addition to the $\mathrm{SiP}_{2} \mathrm{O}_{7}$ lines, there are $\mathrm{SiO}_{2}$ lines available. Quantitative analysis showed 19\% pyrophosphate and $81 \%$ oxide of silicon. Thus, the formation mechanism of the binders in the silicon system with $\mathrm{H}_{3} \mathrm{PO}_{4}$ is disclosed.

Of particular note, the salts of pyrophosphoric acid $\mathrm{H}_{4} \mathrm{P}_{2} \mathrm{O}_{7}$ are formed, but orthophosphoric acid $\mathrm{H}_{3} \mathrm{PO}_{4}$ was added to the mixture. This fact is explained by the polymorphic transformation of the acid, which occurs at approximately $215^{\circ} \mathrm{C}[11,25-27]$. Probably, the transformation is also the reason for the long process of strengthening the mixture (1-2 hours). As a result, for the first time, pyrophosphate is the binder in foundries. In addition, for the first time, it was received directly from a part of the refractory filler.

The differential thermal analysis of the sample was performed in an alundum crucible in air with a heating rate of $20-30^{\circ} \mathrm{C} / \mathrm{min}$ in the interval of $20-1000^{\circ} \mathrm{C}$ (Figure 2). The binders are not subjected to thermal decomposition or other transformations. The endothermic effect at $570^{\circ} \mathrm{C}$ attributes to the conversion of $\alpha$-quartz to $\beta$-quartz (since approximately $81 \% \mathrm{SiO}_{2}$ is present in the sample).

The advantages of the investigated binding system also include the absence of gas emission, as evidenced by the stability of the mass (Figure 2) at high temperature.

Zircon filler is also widely used in core mixtures. It is zirconium silicate $\left(\mathrm{ZrO}_{2} \cdot \mathrm{SiO}_{2}\right.$ or $\left.\mathrm{ZrSiO}_{4}\right)$. We have found that the addition of $\mathrm{H}_{3} \mathrm{PO}_{4}$ makes it possible to strengthen the mixture with such fillers at $330-360^{\circ} \mathrm{C}$. Zircon and $\mathrm{H}_{3} \mathrm{PO}_{4}$ also form binders, the composition and structure of which need to be researched.

The composition of 5 mass units of dust zircon and 3 mass units of $85 \%-\mathrm{H}_{3} \mathrm{PO}_{4}$ was mixed and withstood for 1 hour at $350^{\circ} \mathrm{C}$ in the laboratory oven. Exposure has strengthened the composition throughout the volume. Two crystalline phases were interpreted on the diffraction pattern (Figure 3): zircon (its number is 77.6\%) and zirconium pyrophosphate $\mathrm{ZrP}_{2} \mathrm{O}_{7}$ (22.4\%). The formation of 


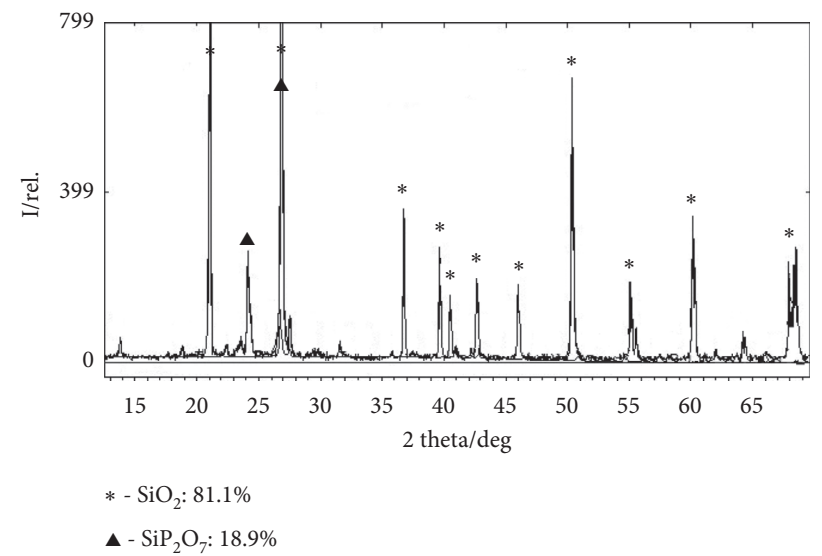

Figure 1: X-ray analysis of the composition of dust silicon (5 mass units) and orthophosphoric acid ( 3 mass units), strengthened at $300^{\circ} \mathrm{C}$.

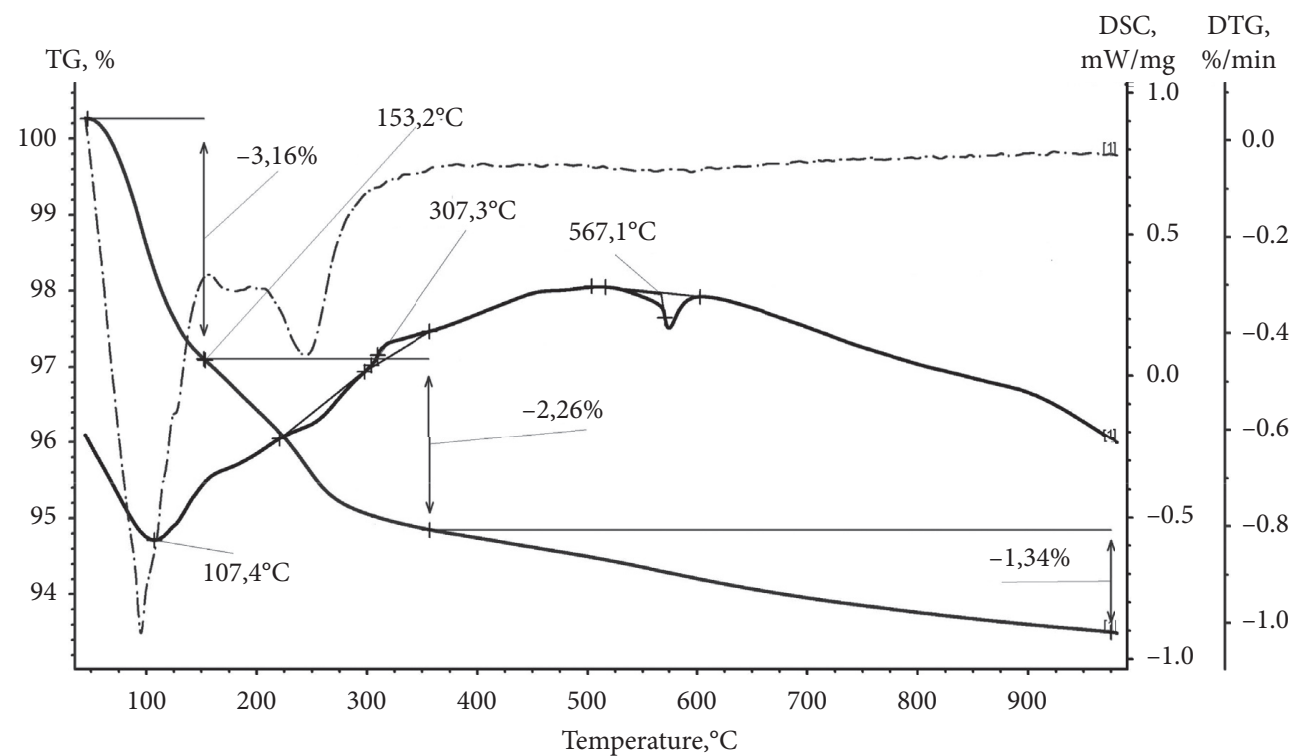

FIgURE 2: Differential thermoanalyses of the composition of dust silicon (5 mass units) and orthophosphoric acid (3 mass units).

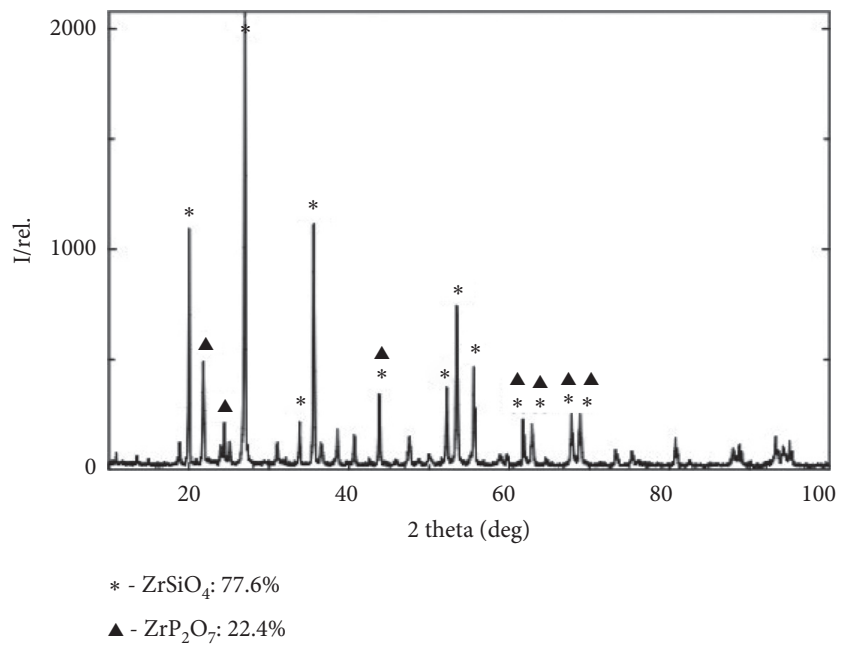

Figure 3: X-ray analysis of the composition of dust zircon (5 mass units) and $\mathrm{H}_{3} \mathrm{PO}_{4}$ (3 mass units), strengthened at $300^{\circ} \mathrm{C}$. zirconium pyrophosphate is the cause of strengthening the sample, so these are binders.

Differential thermoanalysis of this composition (Figure 4) makes it possible to conclude that the thermal stability is high. First, there are no polymorphic transformations when heated to $1000^{\circ} \mathrm{C}$. Secondly, there are no any physicochemical processes in the sample. Thirdly, the mass varies slightly. Thus, these binders are promising for the core mixtures.

Strengthening of mixtures of orthophosphoric acid and kyanite-sillimanite $\left(\mathrm{Al}_{2} \mathrm{O}_{3} \cdot \mathrm{SiO}_{2}\right.$ or $\left.\mathrm{Al}_{2} \mathrm{SiO}_{5}\right)$ occurs in the temperature interval of $250-300^{\circ} \mathrm{C}$. But the phase composition is not so clear. The diffraction pattern of the mixture of 7 mass units of dust kyanite-sillimanite and 3 mass units of $85 \%$ orthophosphoric acid $\mathrm{H}_{3} \mathrm{PO}_{4}$, strengthened at $300^{\circ} \mathrm{C}$, does not allow to establish its complete mineralogical structure (Figure 5).

Three crystalline phases were interpreted on the diffraction pattern: kyanite (or disthene), sillimanite, and 


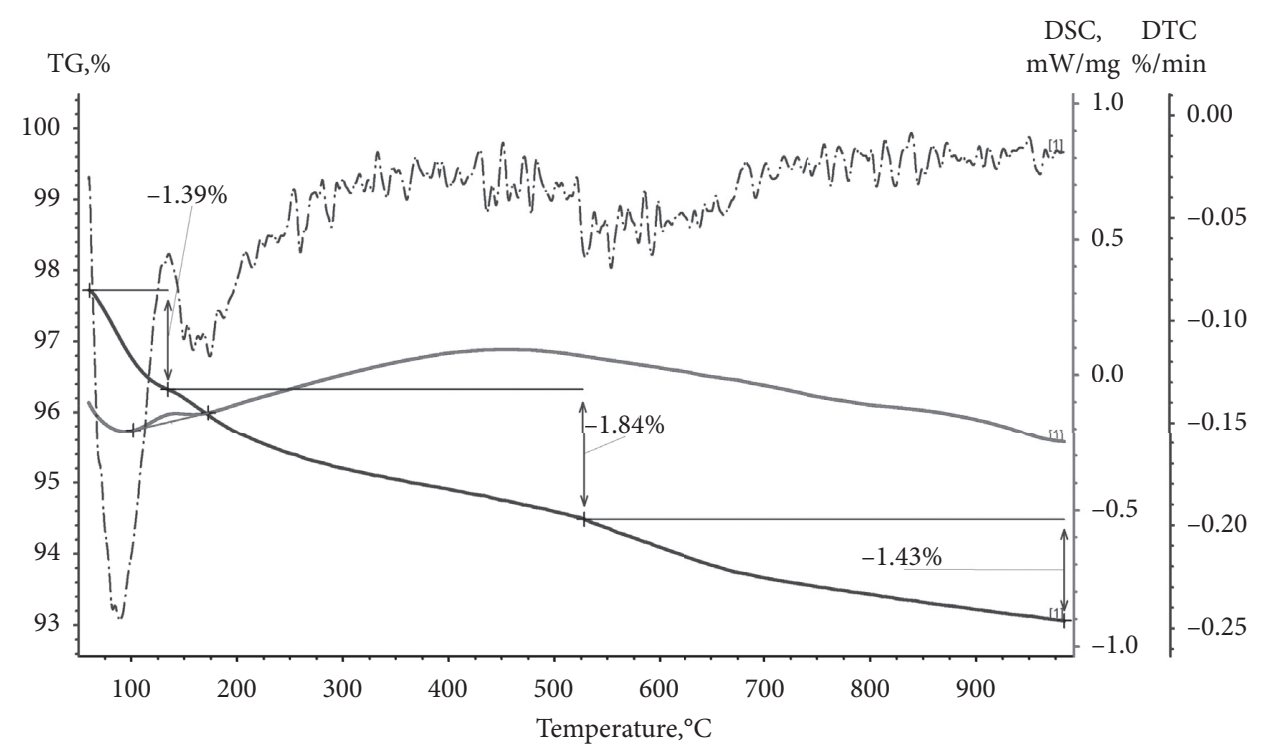

FIGURE 4: Differential thermoanalysis of the composition of dust zircon (5 mass units) and $\mathrm{H}_{3} \mathrm{PO}_{4}$ ( 3 mass units).

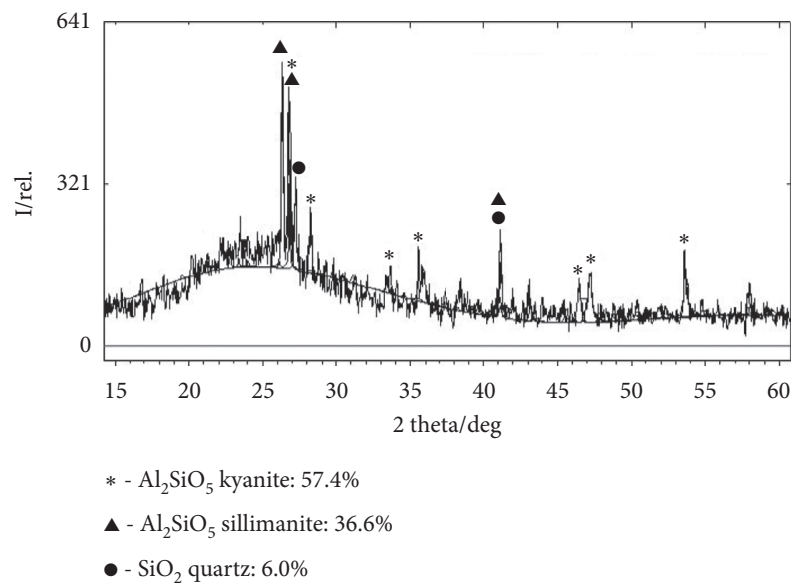

FIGURE 5: X-ray analysis of the composition of kyanite-sillimanite (7 mass units) and orthophosphoric acid (3 mass units), strengthened at $300^{\circ} \mathrm{C}$.

quartz. The phase composition of the sample is almost identical to the composition of kyanite-sillimanite. But binders in this sample were uniquely formed because it was strengthened. Analyzing the distribution of the peaks and their intensities on the diffraction pattern, we conclude that binders in the strengthened state should be attributed to amorphous aluminum hydrophosphates or to their crystal hydrate forms.

As a result of the analysis, we assume that binders were formed by the chemical reaction:

$$
\mathrm{Al}_{2} \mathrm{SiO}_{5}+6 \mathrm{H}_{3} \mathrm{PO}_{4} \longrightarrow 2 \mathrm{Al}\left(\mathrm{H}_{2} \mathrm{PO}_{4}\right)_{3} \cdot 2 \mathrm{H}_{2} \mathrm{O}+\mathrm{SiO}_{2}+\mathrm{H}_{2} \mathrm{O}
$$

By mass ratio, this reaction is fully completed under the condition of 162 mass units of kyanite-sillimanite and 588 mass units of $\mathrm{H}_{3} \mathrm{PO}_{4}$. Our sample, taking into account the acid concentration, contained 980 mass units of kyanite- sillimanite and 500 mass units of $\mathrm{H}_{3} \mathrm{PO}_{4}$. In this case, only 138 mass units of kyanite-sillimanite reacted, and $980-138=842$ mass units remained. Chemical equation (1) should form 51 mass units of quartz.

The calculated composition of the crystalline phases in the sample is $94.3 \%$ of kyanite-sillimanite and $5.7 \%$ of quartz. Phase analysis revealed exactly the same composition, so the assumptions about chemical processes are generally correct. However, nothing is still known about binders, which is in an amorphous state.

In the range of $100-200^{\circ} \mathrm{C}$, aluminum dihydrogen phosphate gradually separates $\mathrm{H}_{2} \mathrm{O}$ molecules. According to chemical equation (1), the initial amount of this hydrophosphate is 648 mass units. In this case, the amount of $\mathrm{H}_{2} \mathrm{O}$ is 62 mass units. It is equal to $4.0 \%$ of the total mass of the sample $(842+51+648)$. According to the DTGA graph (Figure 6), weight loss is close to this and equals $3.6 \%$. Therefore, binders exist in the form of $\mathrm{Al}\left(\mathrm{H}_{2} \mathrm{PO}_{4}\right)_{3}$. Its residual amount is $648-62=586$ mass units.

At a temperature of $417.9^{\circ} \mathrm{C}$, an endothermic effect was recorded, which was accompanied by an insignificant sudden decrease in mass. At this temperature, hydrophosphates can lose constitutional water, and this process is not very simple. It is expressed by the following chemical reactions

$$
\begin{gathered}
\mathrm{Al}\left(\mathrm{H}_{2} \mathrm{PO}_{4}\right)_{3} \longrightarrow \mathrm{AlPO}_{4}+2 \mathrm{H}_{3} \mathrm{PO}_{4} \\
\mathrm{Al}_{2} \mathrm{SiO}_{5}+2 \mathrm{H}_{3} \mathrm{PO}_{4} \longrightarrow 2 \mathrm{AlPO}_{4}+3 \mathrm{H}_{2} \mathrm{O}+\mathrm{SiO}_{2}
\end{gathered}
$$

According to chemical reaction (2), monosubstituted hydrogen phosphate is converted to trisubstituted orthophosphate. This releases a certain amount of active substance $\mathrm{H}_{3} \mathrm{PO}_{4}$. 345 mass units of hydrogen phosphate give 122 mass units of orthophosphate and 196 mass units of $\mathrm{H}_{3} \mathrm{PO}_{4}$. Our sample included 586 mass units of hydrogen phosphate, so 207 mass units of orthophosphate and 333 mass units of $\mathrm{H}_{3} \mathrm{PO}_{4}$ were formed. If free kyanite-sillimanite is present in 


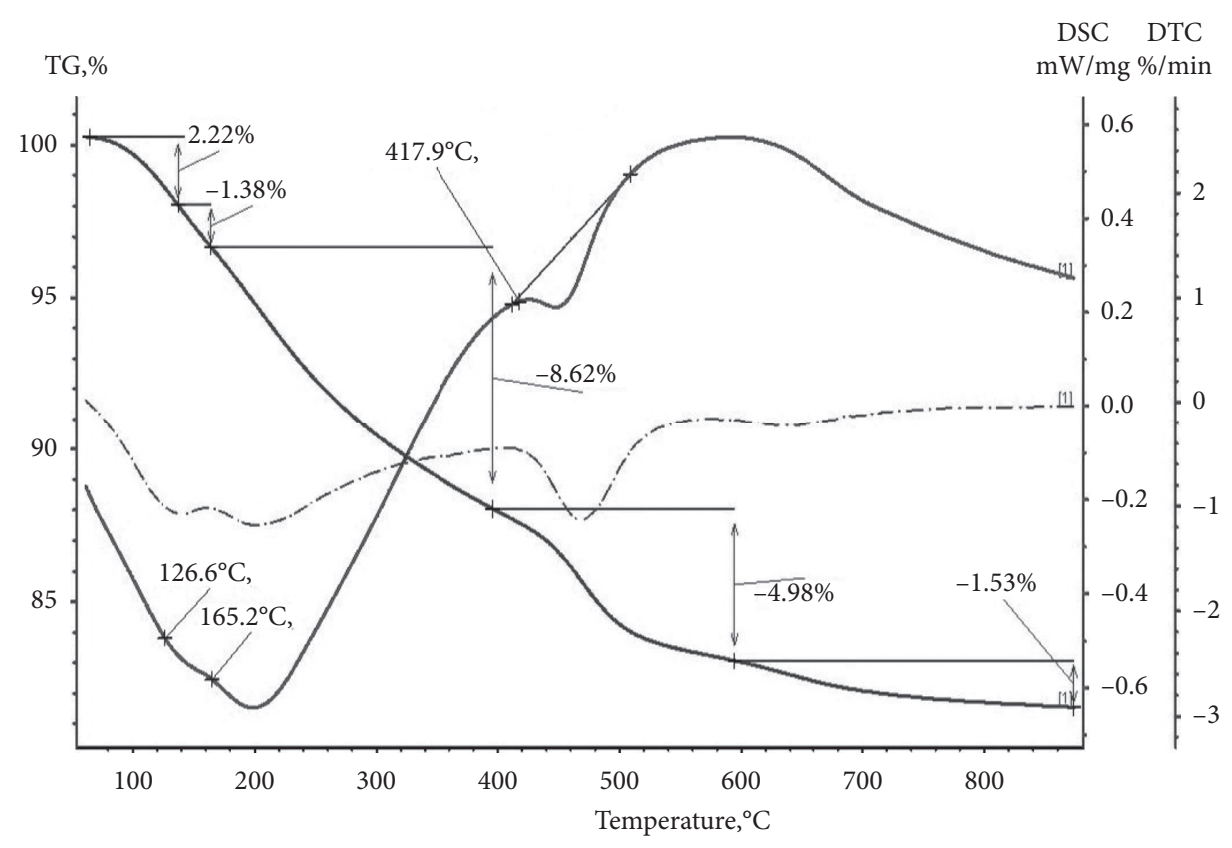

FIgURE 6: Differential thermoanalysis of the composition of kyanite-sillimanite (7 mass units) and orthophosphoric acid (3 mass units).

the sample, then it immediately reacts with $\mathrm{H}_{3} \mathrm{PO}_{4}$. In addition, aluminum orthophosphate is formed.

According to chemical reaction (3) 162 mass units of kyanite-sillimanite react with 196 mass units of $\mathrm{H}_{3} \mathrm{PO}_{4}$ and give 244 mass units of orthophosphate, 54 mass units of water, and 60 mass units of quartz. In our case, 275 mass units of kyanite-sillimanite will react with 333 mass units of $\mathrm{H}_{3} \mathrm{PO}_{4}$, so 415 mass units of orthophosphate, 92 mass units of water, and 102 mass units of quartz are formed.

After these transformations, the sample consists of $842-275=567$ mass units of kyanite-sillimanite $(42 \%)$, $51+102=153$ mass units of quartz (12\%), and $207+415=622$ mass units of aluminum orthophosphate (46\%). The amount of released $\mathrm{H}_{2} \mathrm{O}$ from the total mass of the sample is $6.4 \%$. According to the graph (Figure 6), the weight loss is $6.5 \%$, which exactly coincides with the calculation.

The total smooth heat release in the range of $200-500^{\circ} \mathrm{C}$ is the result of the transition of aluminum phosphate from amorphous to crystalline form. Heating above $500^{\circ} \mathrm{C}$ does not show any thermal effect, i.e., aluminum orthophosphate (as well as quartz and kyanite-sillimanite) is remained unchanged up to $1000^{\circ} \mathrm{C}$.

The obtained data coincide with the results of other researchers $[11,26]$ who have studied the compositions of aluminosilicates (kaolinite and pyrophyllite) with $\mathrm{H}_{3} \mathrm{PO}_{4}$ and also the thermal transformations of widespread aluminophosphate binders. The considered binding composition of kyanite-sillimanite and orthophosphoric acid is suitable for the core mixture.

\section{Conclusions}

The phase composition of binders obtained from the interaction of orthophosphoric acid and refractory fillers, such as dust silicon, zircon, and kyanite-sillimanite, was first investigated.

It is found that the formed binders are $\mathrm{Si}$ and $\mathrm{Zr}$ pyrophosphates and also amorphous $\mathrm{Al}$ phosphates. The formation of pyrophosphates is related to the temperature interval of the strengthened mixtures $\left(250-350^{\circ} \mathrm{C}\right)$, in which orthophosphoric acid is turned into pyrophosphoric acid.

The new binders are thermally stable. This is particularly true for $\mathrm{SiP}_{2} \mathrm{O}_{7}$ and $\mathrm{ZrP}_{2} \mathrm{O}_{7}$, which are characterized by the absence of transformations when heated. Heating of binders formed from kyanite-sillimanite and $\mathrm{H}_{3} \mathrm{PO}_{4}$, causes the crystallization of amorphous phosphates, as well as the transformation of acidic aluminum phosphates to the normal state. This is not detrimental to the characteristics of the core mixture.

\section{Data Availability}

The data used to support the findings of this article are included within the article.

\section{Conflicts of Interest}

The authors declare that they have no conflicts of interest.

\section{References}

[1] A. S. Velichkovich, "Design features of shell springs for drilling dampers," Chemical and Petroleum Engineering, vol. 43, no. 7-8, pp. 458-461, 2007.

[2] L. Ropyak, I. Schuliar, and O. Bohachenko, "Influence of technological parameters of centrifugal reinforcement upon quality indicators of parts," Eastern-European Journal of Enterprise Technologies, vol. 1, no. 5, pp. 53-62, 2016.

[3] O. Bulbuk, A. Velychkovych, V. Mazurenko, L. Ropyak, and T. Pryhorovska, "Analytical estimation of tooth strength, 
restored by direct or indirect restorations," Engineering Solid Mechanics, vol. 7, no. 3, pp. 193-204, 2019.

[4] E.-H. Kim, W.-R. Lee, Y.-G. Jung, and C.-S. Lee, "A new binder system for preparing high strength inorganic molds in precision casting," Materials Chemistry and Physics, vol. 126, no. 1-2, pp. 344-351, 2011.

[5] B. V. Boitsov, L. N. Lesnevskiy, M. A. Lyakhovetskiy et al., "Improving the safety of aluminum press molds by protecting them from wear and corrosion by the microarc oxidation method," Journal of Machinery Manufacture and Reliability, vol. 42, no. 6, pp. 479-485, 2013.

[6] I. P. Shatskyi, L. Y. Ropyak, and M. V. Makoviichuk, "Strength optimization of a two-layer coating for the particular local loading conditions," Strength of Materials, vol. 48, no. 5, pp. 726-730, 2016.

[7] M. Yamshinskij, G. Fedorov, and A. Verkhovliuk, "The development of new casting alloys intended for operation under extreme conditions and some techniques of making castings from them," EUREKA: Physics and Engineering, vol. 2, no. 3, pp. 51-60, 2016.

[8] L. Y. Ropyak, I. P. Shatskyi, I. P. Shatskyi, and M. V. Makoviichuk, "Influence of the oxide-layer thickness on the ceramic-aluminium coating resistance to indentation," Metallofizika I Noveishie Tekhnologii, vol. 39, no. 4, pp. 517524, 2017.

[9] R. M. Tatsiy, O. Y. Pazen, S. Y. Vovk, L. Y. Ropyak, and T. O. Pryhorovska, "Numerical study on heat transfer in multilayered structures of main geometric forms made of different materials," Journal of the Serbian Society for Computational Mechanics, vol. 13, no. 2, pp. 36-55, 2019.

[10] N. Volchenko, A. Volchenko, D. Volchenko et al., "Features of the estimation of the intensity of heat exchange in self-ventilated disk-shoe brakes of vehicles," Eastern-European Journal of Enterprise Technologies, vol. 1, no. 5 (97), pp. 47-53, 2019.

[11] L. G. Sudacas, Phosphate Binding Systems, p. 260, RIA, St. Petersburg, Russia, 2008, in Russian.

[12] S. P. Doroshenko, V. P. Avdokushyn, K. Rusin, and I. Matsechek, "Molding materials and mixtures," Vyshcha Shkola. Kyiv. 1990, SNTI, Prague, Czech Republic, 1991, in Russian.

[13] A. N. Boldin, N. I. Davydov, S. S. Zhukovsky et al., "Foundry molding materials. Forming, core mixtures and coatings,"Mashinostroyeniye, Moscow, Russia, 2006, in Russian.

[14] E. Rodríguez-Senín, A. Várez, B. Levenfeld, J. M. Torralba, and M. A. París, "Processing of Mn-Zn ferrites using mould casting with acrylic thermosetting binder," Powder Metallurgy, vol. 48, no. 3, pp. 249-253, 2005.

[15] J. T. Fox, F. S. Cannon, N. R. Brown, H. Huang, J. C. Furness, and Furness, "Comparison of a new, green foundry binder with conventional foundry binders," International Journal of Adhesion and Adhesives, vol. 34, pp. 38-45, 2012.

[16] L. Solonenko, I. Prokopovitch, I. Prokopovitch, S. Repyakh, K. Sukhoi, and D. Dmytrenko, "System ?nalysis of modern areas of increasing environmental and sanitary hygienic safety of using cold hardening mixtures in foundry," Odes'kyi Politechnichnyi Universytet Pratsi, vol. 1, no. 57, pp. 90-98, 2019.

[17] O. Ponomarenko, T. Berlizeva, I. Grimzin, N. Yevtushenko, and T. Lysenko, "Strength properties control of mixtures based on soluble glass with ethereos solidifiers," Lecture Notes in Mechanical Engineering Advances In Design, Simulation And Manufacturing III, vol. 3, pp. 511-521, 2020.
[18] O. Ponomarenko, N. Yevtushenko, T. Lysenko, L. Solonenko, and V. Shynsky, "A new technology for producing the polystyrene foam molds including implants at foundry industry," Lecture Notes in Mechanical Engineerin, Advances In Design, Simulation And Manufacturing II, vol. 2, pp. 430-437, 2019.

[19] Y. Zhang, D. Liu, X. Lu, Y. Ren, P. Cai, and L. Zhou, "Ferrous sulfate modified phosphate binder and preparation method thereof," Patent China No. 108907069, 2018.

[20] Y. Yang, "Preparation method of modified heat-hardened phosphate cast sand mold," Patent China. No. 106734858, 2017.

[21] H. Liang, D. Xiao, and M. Gan, "High-fluidity phosphate inorganic binder sand and preparation method thereof," Patent China. No. 105964891, 2016.

[22] Y. G. Jung, K. E. Hee, W. T. Kwan, and L. J. Hyun, "Method for preparing casting mold with high strength using ternary inorganic binder," Patent Korea. No. 20180017400\, 2018.

[23] S. Alferyev and V. Polyakov, "Thermoinsulative and thermoconductive concretes based on an aluminophosphate binder (variants)," Patent USA. No. 2014175323, 2014.

[24] A. Heunisch, A. Dellert, and A. Roosen, "Effect of powder, binder and process parameters on anisotropic shrinkage in tape cast ceramic products," Journal of the European Ceramic Society, vol. 30, no. 16, pp. 3397-3406, 2010.

[25] V. A. Dyakonov, V. P. Lunichkina, and N. V. Nefedova, "Investigations of inorganic phosphate binders, workable at high temperatures," Advances in Chemistry and Chemical Technology, vol. 31, no. 6, pp. 79-81, 2017, in Russian.

[26] V. A. Kopeikin, V. S. Klementyeva, and B. L. Krasny, Refractory Solutions Based on Phosphate Binders, Metallurgy, Moscow, Russia, 1986, in Russian.

[27] O. Y. Tikhonenko, V. A. Dyakonov, N. V. Nefedova, and A. A. Stepko, "Investigation of the synthesis processes of modified phosphate binders and refractory compositions based on them," Advances in Chemistry and Chemical Technology, vol. 32, no. 8, pp. 42-44, 2019, in Russian.

[28] A. Cheremysinova, I. Sknar, K. Plyasovskaya, O. Sverdlikovska, O. Sigunov, and O. Demchyshyna, "Study of the anticorrosion effect of polymer phosphates on steel at elevated temperatures," Eastern-European Journal of Enterprise Technologies, vol. 6, no. 12 (90), pp. 52-57, 2017.

[29] I. O. Osypenko, L. I. Solonenko, and O. P. Bilyy, "Systematic use of anthropogenic dust in the composition of cold-hardening phosphate mixtures," System Technologies, vol. 5, no. 118 , pp. $97-104,2018$, in Ukrainian.

[30] S. S. Tkachenko, G. A. Kolodiy, L. G. Znamensky, and A. A. Yermolenko, "Cold-hardening sands based on alumoborphosphate concentrate. Current state and development prospects (inorganics versus organics)," Foundry Technology and Equipment, vol. 3, pp. 33-38, 2018, in Russian.

[31] V. Pohrebennyk, E. Dzhumelia, O. Korostynska, A. Mason, and M. Cygnar, "X-ray fluorescent method of heavy metals detection in soils of mining and chemical enterprises," in Proceedings-2016 9th International Conference on Developments in eSystems Engineering. DeSE, pp. 323-328, Leeds, UK, September 2016.

[32] L. Frolova, A. Derimova, I. Galivets, M. Savchenko, and A. Khlopytskyi, "Investigation of phase formation in the system $\mathrm{Fe} 2+/ \mathrm{Co} 2+/ \mathrm{O} 2 / \mathrm{H} 2 \mathrm{O}$," Eastern-European Journal of Enterprise Technologies, vol. 6, no. 6 (84), pp. 64-68, 2016.

[33] O. P. Makarevych, A. S. Kocheshkov, and R. V. Liutiy, "Molding mixture for molds, strengthened by thermal 
drying," Patent of Ukraine No. 57460 A. MKI 7 B22C1/16, 2003, in Ukrainian.

[34] R. V. Liutyi and D. V. Keush, "Binder system $\mathrm{SiO}_{2}-\mathrm{H}_{3} \mathrm{PO}_{4}$ for foundry cores," Foundry. Technology and Equipment, vol. 4, pp. 23-28, 2017, in Russian.

[35] R. V. Liutyi, M. V. Tyshkovets, and D. V. Liuta, "Foundry core mixtures with orthophosphoric acid and different aluminumcontaining compounds," Фізика і чімія твердоГо тіла, vol. 21, no. 1, pp. 176-184, 2020. 